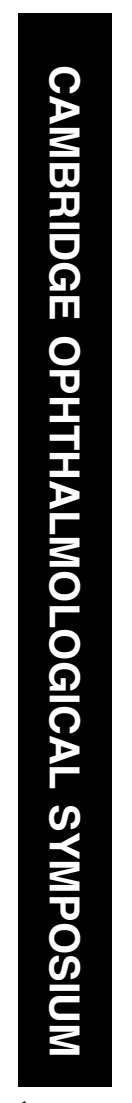

${ }^{1}$ Department of Ophthalmology Emory University School of Medicine Atlanta, GA, USA

${ }^{2}$ Department of Neurology, Emory University School of Medicine Atlanta, GA, USA

${ }^{3}$ Department of Neurological Surgery Emory University School of Medicine Atlanta, GA, USA

Correspondence: NJ Newman MD Neuro-Ophthalmology Unit

Emory Eye Center 1365-B Clifton Road NE Atlanta GA 30322, USA

Tel: + 14047785360

Fax: + 14047784849

E-mail: ophtnjn@ emory.edu

Received: 4 September 2003

Accepted: 4 September 2003

\section{Hereditary optic neuropathies}

\author{
Abstract \\ Aims To provide a clinical update on the \\ hereditary optic neuropathies. \\ Methods Review of the literature. \\ Results The hereditary optic neuropathies \\ comprise a group of disorders in which the \\ cause of optic nerve dysfunction appears to be \\ hereditable, based on familial expression or \\ genetic analysis. In some hereditary optic \\ neuropathies, optic nerve dysfunction is \\ typically the only manifestation of the disease. \\ In others, various neurologic and systemic \\ abnormalities are regularly observed. \\ Conclusion The most common hereditary \\ optic neuropathies are autosomal dominant \\ optic atrophy (Kjer's disease) and maternally \\ inherited Leber's hereditary optic neuropathy. \\ We review the clinical phenotypes of these \\ and other inherited disorders with optic nerve \\ involvement. \\ Eye (2004) 18, 1144-1160. \\ doi:10.1038/sj.eye.6701591
}

Keywords: Leber's hereditary optic neuropathy; autosomal dominant optic atrophy; Kjer's disease; hereditary optic neuropathy; optic atrophy; mitochondrial disease; visual loss

The hereditary optic neuropathies comprise a group of disorders in which the cause of optic nerve dysfunction appears to be hereditable, based on familial expression or genetic analysis. ${ }^{1,2}$ Clinical variability, both within and among families with the same disease, often makes recognition and classification difficult. Traditionally, classification has relied on the recognition of similar characteristics and similar patterns of transmission, but genetic analysis now permits the diagnosis of the hereditary optic neuropathies in the absence of family history or in the setting of unusual clinical presentations. As a result, the clinical phenotypes of each disease are broader, and it is easier to recognize unusual cases.

The inherited optic neuropathies typically present as symmetric, bilateral, central visual loss. In many of these disorders, the papillomacular nerve fibre bundle is affected, with resultant central or cecocentral scotomas. The exact location of initial pathology along the ganglion cell and its axon, and the pathophysiologic mechanisms of optic nerve injury remain unknown. Optic nerve damage is usually permanent and, in many diseases, progressive. Once optic atrophy is observed, substantial nerve injury has already occurred.

In classifying the hereditary optic neuropathies, it is important to exclude the primary retinal degenerations that may masquerade as primary optic neuropathies because of the common finding of optic disc pallor. Retinal findings may be subtle, especially among the cone dystrophies, where optic nerve pallor may be an early finding. The possibility of a primary retinal process should be considered in patients with temporal optic atrophy even when the retina itself is not obviously abnormal. Retinal arterial attenuation and abnormal electroretinography should help distinguish these diseases from the primary optic neuropathies.

Customary classification of the inherited optic neuropathies is by pattern of transmission. The most common patterns of inheritance include autosomal dominant, autosomal recessive, and maternal (mitochondrial). The same genetic defect may not be responsible for all pedigrees with optic neuropathy inherited in a similar fashion. Similarly, different genetic defects may cause identical or similar phenotypes - some inherited in the same manner, others not. Alternatively, the same genetic defect may result in different clinical expressions, although the pattern of inheritance should be consistent. To complicate matters further, single cases are often presumed or proven to be caused by inherited genetic defects, making the pattern of familial transmission unavailable as an aid in classification.

In some of the hereditary optic neuropathies, optic nerve dysfunction is typically the only manifestation of the disease. In others, various neurologic and systemic abnormalities are regularly observed. Additionally, inherited 
diseases with primarily neurologic or systemic manifestations, such as the multisystem degenerations, can include optic atrophy.

The hereditary optic neuropathies reflect a number of different inheritance patterns and can be caused by defects in either the nuclear or mitochondrial genomes. As more specific genetic defects are discovered, our concept of the phenotypes of these disorders will likely change, as will our classification. More accurate definition of the underlying genetic abnormalities will aid genetic counselling. Furthermore, identification of the gene defect, elucidation of the gene product and its normal function, and clarification of the abnormality caused by the mutation should improve our understanding of the pathophysiologic mechanisms of optic nerve dysfunction and allow for the development of directed therapies.

\section{Leber's hereditary optic neuropathy}

In 1871, Leber ${ }^{3}$ first described the disease that bears his name, although similar cases were reported 50 years earlier (e. g., von Graefe ${ }^{4}$ ). Numerous pedigrees of Leber's hereditary optic neuropathy (LHON) have since been reported worldwide. ${ }^{5-14}$ Since the late 1980s, LHON has received notoriety as a maternally inherited disease linked to abnormalities in mitochondrial DNA. ${ }^{2,7,9,11,14-20}$ Genetic analysis has broadened our view of what constitutes the clinical presentation of LHON.

Despite multiple studies describing hundreds of patients with LHON worldwide, the actual prevalence and incidence of visual loss from this disorder has been only rarely and geographically selectively investigated. Among individuals in the North East of England, there was a minimal prevalence of visual loss from LHON of 3.22 per 100000 individuals and a prevalence for harbouring a primary LHON-associated mtDNA mutation of 11.82 per 100000 individuals. ${ }^{21,22}$ In Australia, the disease accounts for about $2 \%$ of legal blindness in individuals under age 65 years and for about $11 \%$ of all patients with bilateral optic neuropathy of uncertain aetiology. ${ }^{23-25}$

Men are affected with visual loss more frequently than women, with a male predominance of about 80 to $90 \%$ in most pedigrees. ${ }^{6-10}$ Approximately 20 to $60 \%$ of men at risk for LHON experience visual loss. ${ }^{6,23,24,} 26$ Among women at risk, the occurrence rate ranges from 4 to $32 \% .^{6,23,24,26}$ Affected females are more likely to have affected children, especially daughters, than unaffected female carriers. ${ }^{6,27}$ Mackey $^{23,24}$ reported that approximately $20 \%$ of male and $4 \%$ of female carriers in Australia lose vision. Mackey and $\mathrm{Howell}^{28}$ noted that there has been a dramatic decline in the risk of visual loss among pedigrees with LHON in Australia and a definite decrease in penetrance over the past century.

The onset of visual loss typically occurs between the ages of 15 and 35 years, but otherwise classic LHON has been reported in many individuals both younger and older, $^{5-7,9-11}$ with a range of age at onset from 2 to 80 years. This age variability occurs even among members of the same pedigree.

Visual loss typically begins painlessly and centrally in one eye. The second eye is usually affected weeks to months later. Reports of simultaneous onset are numerous $^{5-7}$ and likely reflect both instances of true bilateral coincidence and those in which initial visual loss in the first eye went unrecognized. Rarely, loss of vision in the second eye occurs after a prolonged interval (more than 12 years) or, even more infrequently, visual loss remains monocular. ${ }^{11}$ In general, however, greater than $97 \%$ of patients will have second eye involvement within 1 year. ${ }^{7,9}$

The onset of visual loss is usually not associated with other symptoms. Uhthoff's symptom (a transient worsening of vision with exercise or warming) may occur in patients with LHON, as it does in patients with other optic neuropathies. Other reported symptoms at the time of visual loss are usually minor and nonspecific, such as headache; eye discomfort; flashes of light, colour, or both; limb paresthesias; and dizziness. ${ }^{5-7,9}$

The duration of progression of visual loss in each eye also varies and may be difficult to document accurately. Usually, the course is acute or subacute, with deterioration of visual function stabilizing after months. ${ }^{5-7,11}$ In one study of molecularly confirmed LHON, progression of visual loss in each eye ranged from 'sudden and complete' to 2 years, with a mean of 3.7 months. ${ }^{7}$ Nikoskelainen et $a l^{11}$ described rare patients with slowly progressive visual loss, ultimately with a favourable visual outcome.

Visual acuities at the point of maximum visual loss range from no light perception to $20 / 20$, with most patients deteriorating to acuities worse than $20 / 200 .^{5-7,9,11}$ Colour vision is affected severely, often early in the course, but rarely before significant visual loss. ${ }^{11}$ The Farnsworth-Munsell 100-Hue test may be the earliest indicator of optic nerve dysfunction, but subtle abnormalities of colour vision can be demonstrated in asymptomatic family members. ${ }^{29}$ Pupillary light responses may be relatively preserved when compared with the responses in patients with optic neuropathies from other causes, ${ }^{11,30}$ although others have not confirmed this finding. ${ }^{31}$

Visual field defects are typically central or cecocentral $^{6,7,11,29}$ (Figure 1). Apparently unaffected eyes may show subtle cecocentral scotomas only to red test objects or as mild depression on central automated 



Figure 1 Leber's hereditary optic neuropathy. (a and b) Optic nerve appearance in a patient with bilateral visual loss. (a) The right optic nerve is pale consistent with visual loss of several months' duration. (b) The left optic nerve appears hyperaemic without true disc oedema at the time of visual loss. There are papillary telangiectasias. (c) Goldmann visual fields showing central defects in both eyes.

perimetry. Field abnormalities mimicking the bitemporal configuration of chiasmal defects have also been reported. ${ }^{32,33}$ In a few of these cases, the defects have strictly respected the vertical meridian.

Even the earliest descriptions of this disease noted funduscopic abnormalities other than optic atrophy. ${ }^{3}$ Especially during the acute phase of visual loss, hyperaemia of the optic nerve head, dilation and tortuosity of vessels, retinal and disc haemorrhages, macular oedema, exudates, retinal striations, and obscuration of the disc margin were recognized in some cases. In 1973, Smith et al ${ }^{34}$ reported a triad of signs believed pathognomonic for LHON: circumpapillary telangiectatic microangiopathy, swelling of the nerve fibre layer around the disc (pseudoedema), and absence of leakage from the disc or papillary region on fluorescein angiography (distinguishing the LHON nerve head from truly oedematous discs) ${ }^{34}$ (Figure 1).
Nikoskelainen et al ${ }^{11}$ observed these funduscopic changes in all of their symptomatic patients with LHON, some of their 'presymptomatic' cases, and in a significant proportion of asymptomatic maternal relatives. However, having abnormalities of the peripapillary nerve fibre layer does not necessarily predict visual loss. Furthermore, some patients with LHON never exhibit the characteristic ophthalmoscopic appearance, even if examined at the time of acute visual loss. ${ }^{7,9,10}$ In one review, 22 of 52 patients did not have any abnormal funduscopic findings. ${ }^{7}$ In another review, $36 \%$ of 33 patients examined within 3 months of visual loss did not have retinal microangiopathy. ${ }^{9}$ The 'classic' LHON ophthalmoscopic appearance may be helpful in suggesting the diagnosis if recognized in patients or their maternal relatives, but its absence - even during the period of acute visual loss-does not exclude the diagnosis of LHON. As the disease progresses, the 
telangiectatic vessels disappear and the pseudo-oedema of the disc resolves. Perhaps because of the initial hyperaemia, the optic discs of patients with LHON may not appear pale for some time. This feature, coupled with the relatively preserved pupillary responses and the lack of pain, has led to the misdiagnosis of nonorganic visual loss in some LHON patients. ${ }^{33}$ Eventually, however, optic atrophy with nerve fibre layer dropout most pronounced in the papillomacular bundle supervenes.

Nonglaucomatous cupping of the optic discs or arteriolar attenuation may also be seen in patients with symptomatic LHON.

In most patients with LHON, visual loss remains profound and permanent. However, not uncommonly, recovery of even excellent central vision occurs years after visual deterioration. 6,7,9,11,35 The recovery may occur gradually over 6 months to 1 year after initial visual loss or may suddenly occur up to 10 years after onset. ${ }^{36} \mathrm{It}$ may take the form of a gradual clearing of central vision or be restricted to a few central degrees, resulting in a small island of vision within a large central scotoma. ${ }^{35}$ Recovery is usually bilateral but may be unilateral. Those patients whose vision improves most substantially appear to have a lower mean age at the time of initial visual loss. ${ }^{9,11}$ In the review by Riordan-Eva et $a l^{9}$ of 79 cases from 55 families, good visual outcome was strongly correlated with age at onset, all those with onset before 20 years having a final visual acuity better than 20/80. Furthermore, the particular mitochondrial DNA mutation also influences prognosis, with the 11778 mutation carrying the worst prognosis for vision, and the 14484 mutation the best (see below). Recurrences of visual failure are extremely rare among those patients both with and without visual recovery.

In the majority of patients with LHON, visual dysfunction is the only significant manifestation of the disease. However, some pedigrees have members with associated cardiac conduction abnormalities, especially the pre-excitation syndromes. ${ }^{37-41}$

Minor neurologic abnormalities, such as exaggerated or pathologic reflexes, mild cerebellar ataxia, tremor, movement disorders, myoclonus, seizures, muscle wasting, distal sensory neuropathy, motor neuropathy, and migraine, have been reported in patients with LHON. ${ }^{6,42,43}$ Less commonly, pedigrees have been described in which multiple maternal members demonstrate the clinical features of LHON in addition to more severe neurologic abnormalities. We have termed these pedigrees 'Leber's Plus'. ${ }^{16}$ The maternal members of a large Australian family demonstrate varied combinations of optic atrophy, movement disorders, spasticity, psychiatric disturbances, skeletal abnormalities, and acute infantile encephalopathic episodes. ${ }^{44}$ A Leber's-like optic neuropathy has been associated with dystonia and basal gangliar lesions in several pedigrees. ${ }^{45-50}$ Leigh-like encephalopathy, periaqueductal syndrome and other brainstem involvement have also rarely been reported..$^{51-53}$

Disease clinically indistinguishable from multiple sclerosis may occur in families with LHON. 9,42,54,55 Harding et $a l^{54}$ reported molecularly confirmed 11778 pedigrees of LHON with individuals, especially females, exhibiting symptoms and signs of demyelinating disease combined with nonremitting visual loss typical of LHON. Cerebrospinal fluid and MR imaging findings were characteristic of multiple sclerosis. Subsequent population surveys have not found the primary mutations associated with LHON to be overrepresented among multiple sclerosis patients. ${ }^{56,57}$ However, among multiple sclerosis patients selected specifically because of their prominent early optic neuropathy, the primary LHON mutations may be found more frequently. ${ }^{56}$ It is possible that this association between LHON and multiple sclerosis is no greater than the prevalence of the two diseases. An underlying LHON mutation, however, may worsen the prognosis of optic neuritis in patients with multiple sclerosis. ${ }^{55,57,58}$

Ancillary tests, aside from genetic analysis, are generally of limited usefulness in the evaluation of LHON. CT scanning and MR imaging of the brain are typically normal in patients with LHON. ${ }^{7,59}$ Exceptions include those patients with additional symptoms suggestive of multiple sclerosis and those pedigrees with dystonia and basal gangliar lesions. One boy with LHON-visual loss but no symptoms or signs suggestive of demyelinating disease was found to have extensive T2-hyperintense periventricular white matter changes. ${ }^{60}$ Two LHON patients were reported with distended optic nerve sheaths on orbital ultrasonography, CT scanning, and MR imaging. ${ }^{61,62} \mathrm{MR}$ imaging of the optic nerves of symptomatic LHON patients typically reveals normal nerves in the acute phase of visual loss, often followed by high T2 signals in the intraorbital portions of the nerves after several months. ${ }^{9,59,63-65}$ Rarely, gadolinium enhancement and enlargement of the optic nerves and even chiasm may be demonstrated during the acute phase of visual loss. ${ }^{66-68}$

In no case do we have optic nerve pathology from the early stages of the disease; hence, the location and nature of the initial injury remain uncertain. Kerrison et al ${ }^{69}$ noted marked atrophy of the nerve fibre and retinal ganglion cell layers and the optic nerves on a postmortem study of an 81-year-old affected woman from the large Australian family with 'Leber's Plus'. ${ }^{44}$ Electron microscopy demonstrated retinal ganglion cell inclusions consisting of calcium circumscribed by a double membrane, suggesting intramitochondrial 
calcification. Histopathologic and morphometric analysis was performed on optic nerves from three other LHON patients, again years remote from the time of acute visual loss. ${ }^{70,71}$ Findings consisted of severe generalized depletion of optic nerve fibres (95-99\% reduction), with sparing of only peripheral clusters of fibres, primarily those of larger diameter. There was fibrocytic scarring, scattered 'degeneration dust', and evidence of minimal inflammation. These authors propose a selective loss of the ganglion cell P-cell population. ${ }^{70,71}$

All pedigrees clinically designated as LHON have a maternal inheritance pattern, confirming the disease's association with point mutations in the mitochondrial genome (see the accompanying article in this volume on the molecular genetics of optic neuropathies). ${ }^{9,15,17,19,20,72}$ Three point mutations in the mitochondrial DNA (mtDNA), the so-called 'primary' LHON mutations, are believed to cause 90 to $95 \%$ of cases of LHON worldwide. They are located at mtDNA positions 11778 (69\% of cases), 3460 (13\% of cases), and 14484 (14\% of cases). Several other mtDNA mutations may be 'primary', but account individually for only a few pedigrees worldwide. ${ }^{72}$ Other mtDNA point mutations have been associated with LHON, but their pathogenetic significance remains less clear.

Genetic analysis allows a broader view of what constitutes the clinical profile of LHON. ${ }^{2,16}$ Most striking are the number of patients without a family history of visual loss. Although there is undoubtedly a referral bias for the unusual cases, it is still quite remarkable that singleton cases constituted $57 \%$ of one series of molecularly confirmed LHON. ${ }^{7}$ In contrast, Mackey ${ }^{23}$ reported only a small proportion of singleton cases in Australia, suggesting ascertainment difficulties or low penetrance in America. The use of high-resolution mtDNA haplotypes to aggregate multiple apparently unrelated pedigrees affected with LHON into single large maternal lineages descending from the same founder ${ }^{73,74}$ may decrease the number of true singleton cases. Some of these singleton cases are women, some outside the typical age range for LHON, some without the classic ophthalmoscopic appearance. ${ }^{33}$ Clearly, the diagnosis of LHON should be considered in any case of unexplained bilateral optic neuropathy, regardless of age of onset, sex, family history, or funduscopic appearance.

Many questions remain unanswered regarding the determinants of phenotypic expression in LHON. For instance, does the specific mtDNA mutation dictate particular clinical features? Although those pedigrees with LHON 'plus' demonstrate that certain mtDNA mutations may result in specific disease patterns of Leber's-like optic neuropathies with other neurologic abnormalities, ${ }^{20}$ few significant clinical differences have been demonstrated to date among those LHON patients positive for the 11778 mutation, those with other mtDNA mutations, and those as yet genetically unspecified. One major exception is the difference in spontaneous recovery rates among those patients with the 11778 mutation and those with the 14484 mutation. Among 136 patients with the 11778 mutation, only five $(4 \%)$ reported spontaneous recovery, ${ }^{35}$ compared with $37-65 \%$ of 14484 patients. ${ }^{9,11}$ Furthermore, the ultimate visual acuities in patients with the 14484 mutation are significantly better than those with the 11778 and 3460 mutations. ${ }^{9}$

Except for rare examples of de novo occurrence of a primary LHON mutation, ${ }^{75}$ a mtDNA mutation will be present in all maternally related family members of patients with LHON, even though many will never become symptomatic. Hence, whereas the presence of an mtDNA mutation may be necessary for phenotypic expression, it may not be sufficient. Heteroplasmy for the primary LHON mutations has been demonstrated in several affected and unaffected individuals, and the degree of heteroplasmy may correlate with the risk of visual loss. ${ }^{76}$ However, in most large reviews of molecularly confirmed LHON patients, heteroplasmy is documented in the blood of a minority of affected individuals. ${ }^{7,22,27}$

Other genetic factors besides the specific mtDNA mutation and the presence and degree of heteroplasmy may play a role in expression. Although some investigators have claimed that multiple LHONassociated mtDNA mutations may be necessary for visual loss, this has not been corroborated in several studies. 9,11,77 Indeed, case reports of unaffected individuals who even harbour two primary mutations ${ }^{78,79}$ make this claim improbable. Similarly, although the underlying mtDNA haplotype may influence the presence, penetrance, or expression of an mtDNA point mutation, ${ }^{80}$ this is unlikely to be the major factor in phenotypic expression. Nuclear-encoded factors modifying mtDNA expression, mtDNA products, or mitochondrial metabolism may influence phenotypic expression of LHON. Although most studies have not been able to confirm X-linkage as an explanation of the male predominance of visual loss in LHON, the $\mathrm{X}$-linkage hypothesis may still be viable. ${ }^{20}$

Tissue energy utilization and reserve in an individual may also determine the timing and extent of visual loss. Mitochondrial energy production decreases with age, ${ }^{81}$ and the timing of visual loss in patients at risk for LHON may reflect the threshold at which already reduced mitochondrial function deteriorates to a critical level. Immunologic factors have also been proposed, especially to explain the association of LHON with multiple sclerosis, ${ }^{54,55}$ but conclusive evidence is lacking. Finally, 
environmental factors, both internal and external, may play a role. Systemic illnesses, nutritional deficiencies, medications, or toxins that stress or directly or indirectly inhibit mitochondrial metabolism have been suggested to initiate or increase phenotypic expression of the disease. However, widespread nutritional deficiency in Cuba did not appear to increase the expression of LHON in one large 11778-positive pedigree. ${ }^{82}$ Similarly, although anecdotal reports suggest a possible role for tobacco and excessive alcohol use as precipitants of visual loss, one lare case-control study of sibships ${ }^{83}$ failed to confirm this. Other agents known to be toxic to the optic nerve, such as ethambutol, 84,85 or to mitochondrial function, such as antiretroviral therapy, ${ }^{86-88}$ may have a heightened toxicity in patients with the LHON mutations and already compromised mitochondrial function.

Theories on the pathogenesis of LHON must reconcile how multiple different mtDNA mutations located in different genes encoding different proteins result in an essentially identical clinical phenotype that is expressed only in the optic nerve, suddenly and bilaterally. ${ }^{72,89-91}$ Pathogenetic theories include reduction in ATPproduction and/or free-radical damage with resultant apoptosis of retinal ganglion cells. Selective involvement of the ganglion cell or its axon may be explained on a vascular, mechanical, or regional basis, with several studies suggesting a high degree of mitochondrial respiratory activity within the unmyelinated, prelaminar portion of the optic nerve. ${ }^{72}$ This portion of the visual system may be particularly vulnerable to mitochondrial dysfunction, especially abnormalities of complex I. ${ }^{92}$ Further elucidation of the genetic and environmental triggers of the pathologic cascade in susceptible individuals will require more genetic, biochemical, physiological, and pathologic studies. ${ }^{72}$

In light of the possibility for spontaneous recovery in some patients with Leber's disease, any anecdotal reports of treatment efficacy must be considered with caution. Reports from Japan advocated craniotomy with lysis of chiasmal arachnoid adhesions in patients with LHON, with $80 \%$ of more than 120 patients reporting visual improvement. ${ }^{93,94}$ Although the data are impressive, it is difficult to support a surgical therapy logistically removed from the site of ocular neurovascular changes. Some manifestations of other mitochondrial diseases, specifically the mitochondrial cytopathies, may respond to therapies designed to increase mitochondrial energy production. ${ }^{95}$ Most of the agents used are naturally occurring cofactors involved in mitochondrial metabolism, while others have antioxidant capabilities. Therapies tried include coenzyme $\mathrm{Q}_{10}$, idebenone, L-carnitine, succinate, dichloroacetate, vitamin $K_{1}$, vitamin $K_{3}$, vitamin $C$, thiamine, vitamin $B_{2}$, and vitamin E. Mashima et al ${ }^{96}$ reported on $28 \mathrm{LHON}$ patients, 14 of whom were treated with idebenone (a quinol that stimulates ATP formation) combined with vitamin $B_{2}$, and vitamin $C$. There was no significant difference in the number of eyes with visual recovery, although the authors claimed that the treatment seemed to speed recovery when it occurred. Topical agents deemed neuroprotective or antiapoptotic for ganglion cells could be administered directly to the eye. ${ }^{97}$ It remains to be seen whether any of these agents alone or in combination will prove consistently useful in the treatment of acute visual loss in LHON, in the prevention of second eye involvement, or in the prophylactic therapy of asymptomatic family members at risk.

A promising form of gene therapy known as allotypic expression may play a future role in the therapy of LHON and other mitochondrial diseases. ${ }^{98}$ In this approach, a nuclear-encoded version of a gene normally encoded by mtDNA (in this case the ND4 gene containing nucleotide position 11778) is made synthetically, inserted via an adeno-associated viral vector, and codes for a protein expressed in the cytoplasm that is then imported into the mitochondria. This protein increased the survival of cybrids harbouring the 11778 mutation three-fold and restored ATP synthesis to a level indistinguishable from that in cybrids containing normal mtDNA. The relative accessibility of the eye and its ganglion cells may provide the ideal setting in which to test this nuclear solution of a mitochondrial problem. ${ }^{99}$

Nonspecific recommendations to avoid agents that might stress mitochondrial energy production have no proven benefit in LHON, but are certainly reasonable. We advise our patients at risk for LHON to avoid tobacco use, excessive alcohol intake, and environmental toxins. An ECG should be obtained and any cardiac abnormalities treated accordingly. Considering the degree of visual acuity loss, it is remarkable that van Senus ${ }^{6}$ reported $82 \%$ of patients gainfully employed despite their visual handicap. Low vision assessment may be helpful, especially because much of the useful peripheral vision may remain intact. Finally, the importance of genetic counselling in this disease should not be underestimated.

\section{Dominant optic atrophy}

Autosomal dominant optic atrophy, type Kjer (McKusick no. 165500, gene symbol OPA1), is believed to be the most common of the hereditary optic neuropathies. The estimated disease prevalence is 1:50000 or as high as $1: 10000$ in Denmark. ${ }^{100,101}$

In addition to the cases described by $\mathrm{Kjer}^{102,103}$ numerous other studies have established the clinical profile of patients with dominantly inherited optic 
atrophy. ${ }^{101,104-113}$ It is generally agreed that dominant optic atrophy (DOA) is an abiotrophy with usual onset in the 1st decade of life. Kjer ${ }^{102,103}$ noted that many of his patients were ignorant of the familial nature of their disease and, in fact, did not realize that they, themselves, had visual dysfunction. No individual in the series by Kline and Glaser ${ }^{106}$ could identify a precise onset of reduced acuity. In Hoyt's series, ${ }^{107}$ the majority of affected patients dated the onset of visual symptoms between 4 and 6 years of age, although a few severely affected individuals were noted to have a visual disturbance, primarily because of nystagmus, prior to beginning schooling. Smith ${ }^{104}$ reviewed the literature up to 1972 on this subject and collected 554 clear-cut cases, of whom 442 were actually examined. He emphasized that of this large group, only 15 patients (2.2\%) were actually observed to have optic atrophy before age 10 years. Similarly, Johnston et al ${ }^{113}$ reported visual symptoms before the age of 10 years in only $58 \%$ of their 47 affected individuals. Three of the patients (12.5\%) examined by Kline and Glaser, ${ }^{106}$ seven of Hoyt's ${ }^{107}$ patients $(22.6 \%)$, and five of the patients reported by Elliott et $a l^{108}$ (25\%) were unaware of visual difficulties and were discovered to have optic atrophy as a direct consequence of examination of other affected family members. These phenomena attest to the usually imperceptible onset in childhood, often mild degree of visual dysfunction, absence of night blindness, and absence of acute or subacute progression.

Kjer $^{102,103}$ emphasized that visual acuity was usually reduced to the same mild extent in both eyes. Visual acuity remained between 20/20 and 20/60 throughout life in $40 \%$ of his cases, with severe visual loss (20/200 to $20 / 600$ ) occurring in only $15 \%$. None of the 200 patients examined by $\mathrm{Kjer}^{102}$ had visual acuity reduced to hand motion or light perception levels. His findings are in accordance with the cases collected by Smith, ${ }^{104}$ who found that $37 \%$ had visual acuity of $20 / 60$ or better; $46 \%$ had visual acuity between 20/60 and 20/200; and only $17 \%$ had visual acuity below 20/200. Other studies support this wide range of visual acuities from 20/20 to light perception. ${ }^{106-112}$ In an analysis of 87 affected patients from 21 molecularly confirmed families with DOA, ${ }^{111}$ the mean visual acuity was $20 / 120$. In all studies, a few patients have been found with striking asymmetry between the acuities of the two eyes, and there is considerable interfamilial and intrafamilial variation in acuities. ${ }^{111}$

Kjer $^{102,103}$ was able to obtain follow-up data on 98 patients, 75 of whom were observed for at least 5 years. Some progression occurred in about $50 \%$ of the patients. In addition, in Kjer's ${ }^{103}$ series, no patients below 15 years of age had visual acuity below 20/200, but $10 \%$ of patients $15-44$ years of age and $25 \%$ of patients 45 years and older had vision below 20/200. In a study of 20 patients with a mean follow-up of 16 years, ${ }^{108}$ visual acuity remained stable in both eyes of 13 patients $(65 \%)$, decreased in one eye in three patients $(15 \%)$, and decreased in both eyes in four patients (20\%). There was no correlation between the rate of visual loss and initial visual acuity or individual pedigrees. Votruba et al ${ }^{111}$ documented deterioration of visual acuity with age in one-third of their 21 families. These figures suggest a mild, slow, insidious progression of visual dysfunction in some patients. The observation that some families have a marked decline in visual acuity with age while others do not has important implications for counseling. ${ }^{111}$ Spontaneous recovery of vision is not a feature of this disorder.

In the patients studied by Kjer, ${ }^{102,103}$ there was often an inability to perceive blue colours. Some studies ${ }^{104,106,107}$ subsequently claimed that tritanopia is the characteristic colour vision defect in patients with dominant optic atrophy; however, other studies suggest that a generalized dyschromatopsia, with both blue-yellow and red-green defects, is even more common than an isolated tritanopia. ${ }^{108,111}$ This mixed colour defect accounted for more than $80 \%$ of the colour deficits documented in a large study of 21 pedigrees. ${ }^{111}$

Visual fields in patients with dominant optic atrophy characteristically show central, paracentral, or cecocentral scotomas. In patients with acuities of $20 / 50$ or better, static perimetry is often necessary to identify the defects. The peripheral fields are usually normal in these patients. Smith ${ }^{104}$ collected 22 cases of 'bitemporal hemianopia' detected with coloured test objects. In the large study performed by Votruba et $a l,{ }^{111} 66 \%$ of the visual field defects in 50 affected patients were predominantly in the superotemporal visual fields (Figure 2). This pattern of visual field involvement has been demonstrated using a variety of techniques of field testing, and fixation has been monitored with scanning laser ophthalmoscopy, ${ }^{111}$ suggesting that these superobitemporal defects are not an artefact of the testing procedures or of eccentric fixation.

The optic atrophy in patients with dominantly inherited optic neuropathy may be subtle, ${ }^{103}$ temporal only, ${ }^{104,114}$ or involving the entire optic disc. ${ }^{103}$ Kline and Glaser $^{106}$ found the most characteristic change was a translucent pallor with absence of fine superficial capillaries of the temporal aspect of the disc, with a triangular excavation of the temporal portion of the disc (Figure 2). In the Votruba et al analysis, ${ }^{111}$ wedge-shaped temporal pallor of the disc was documented in $44 \%$ of 172 eyes, total atrophy in another $44 \%$, and subtle diffuse pallor in $12 \%$. Other ophthalmoscopic findings reported in these patients included peripapillary atrophy, absent foveal reflex, mild macular pigmentary changes, arterial 

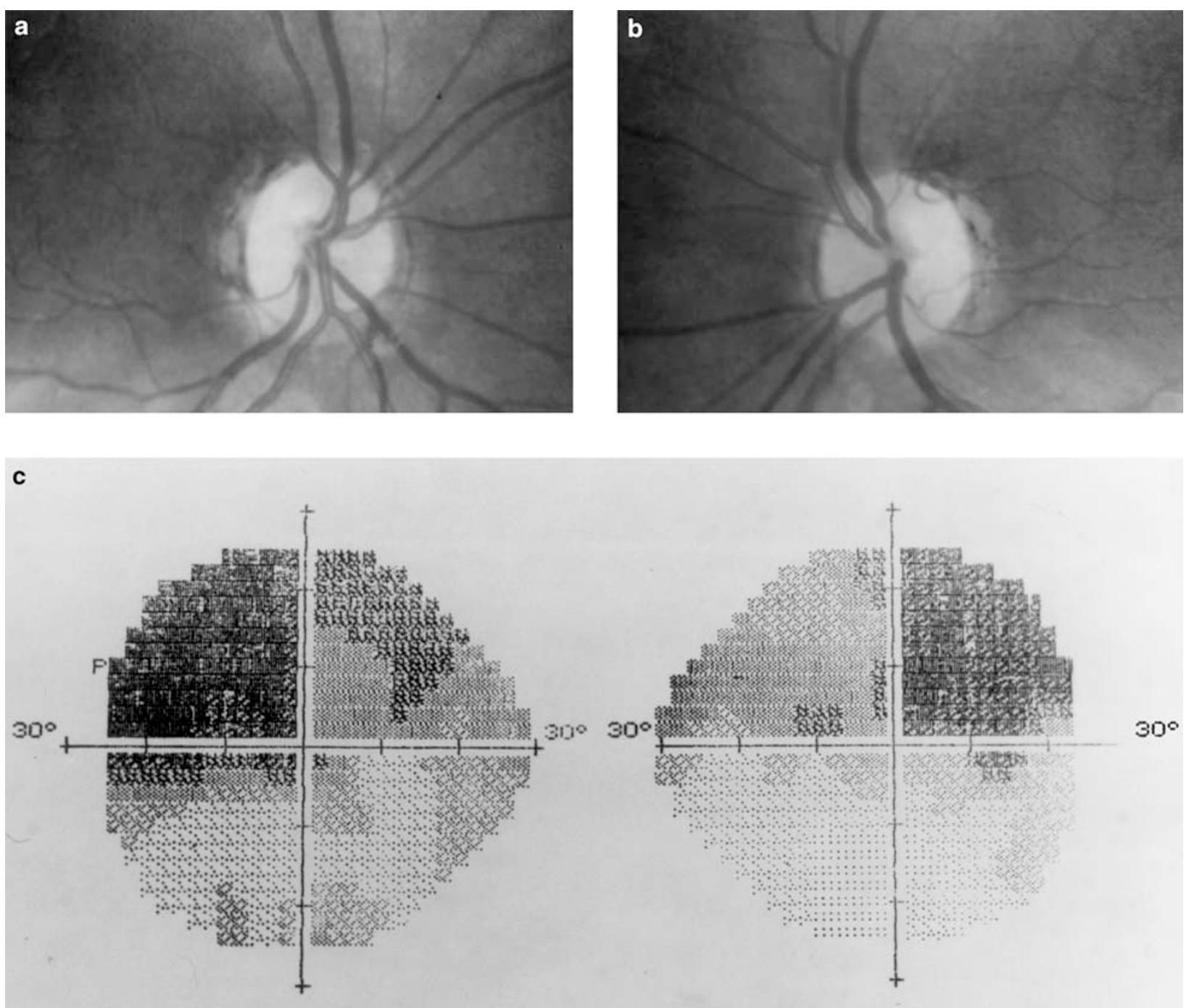

Figure 2 Dominant optic atrophy. (a and b) Bilateral optic nerve pallor in a patient with dominant optic atrophy amd visual acuity of 20/80 OU. There are triangular excavations of the temporal portions of the discs. (c) Goldmann visual fields showing central and superotemporal visual field defects.

attenuation, and nonglaucomatous cupping with absence of a healthy neuroretinal rim and shallow saucerization of the cup. ${ }^{104,106,108,115}$ Fournier et al ${ }^{116}$ emphasized several clinical features that help distinguish patients with DOA from those with normal tension glaucoma, including early age of onset, preferential loss of central vision, sparing of the peripheral fields, pallor of the remaining neuroretinal rim, and a family history of unexplained visual loss or optic atrophy.

Electrophysiologic studies have been performed in several patients with dominant optic atrophy. ${ }^{106,111,117,118}$ Visual-evoked responses in affected individuals characteristically show diminished amplitudes and prolonged latencies, the latter usually less profound than in demyelinating disease. ${ }^{111,117,118}$ Pattern electroretinograms show a reduced N95 component in keeping with primary ganglion cell dysfunction. ${ }^{111}$ Extreme clinical variability among subjects with DOA suggests that on occasion, combined clinical and functional evaluation, with computerized perimetry, tests of contrast sensitivity, and electrophysiologic testing, may be necessary to diagnose the most subtle cases. ${ }^{118}$

Although there are dominantly inherited syndromes of optic atrophy associated with neurologic dysfunction, most of the patients with the syndrome of autosomal dominant optic atrophy have no additional neurologic deficits. Nystagmus in some patients likely reflects early visual deprivation rather than central neurologic involvement. Kjer ${ }^{102,103}$ found mental abnormalities in $10 \%$ of his cases, but this feature was not confirmed in subsequent studies. Eight of 31 patients described by Hoyt ${ }^{107}$ had neural hearing loss, clustering in three of six 
families. Only one patient was aware of any hearing difficulties. More severe hearing loss associated with familial optic atrophy may be a genetically distinct syndrome (see below).

Johnston et al ${ }^{105}$ performed a histologic examination of the eyes and optic nerves of a 56-year-old woman from a family with a typical pedigree of autosomal dominant hereditary optic atrophy. The patient had a long history of bilaterally reduced vision (20/100 in both eyes), bilateral central scotomas, and temporal pallor of both discs. In both eyes, there was diffuse atrophy of the retinal ganglion cell layer associated with diffuse atrophy and loss of myelin within the optic nerves. Johnston et al $^{105}$ suggested, as did Kjer, ${ }^{102,103}$ that dominant optic atrophy is a primary degeneration of retinal ganglion cells. Electrophysiologic studies confirm loss of ganglion cell function predominantly from central retina, but not the exclusive result of either parvocellular or magnocellular cell loss. ${ }^{111}$

One study of a large pedigree of German descent suggested linkage of the gene responsible for dominant optic atrophy with the Kidd blood group antigen, subsequently localized to chromosome $18 \mathrm{q} 12^{112,119}$ (see the accompanying article in this volume on the molecular genetics of optic neuropathies). Further study of this family refined the chromosomal locus to a 3-cM region at 18q12.2-12.3. ${ }^{112}$ This family is clinically similar to the other pedigrees of DOA, including its intrafamilial variation, although the median visual acuity was somewhat better at $20 / 40$.

Most of the other pedigrees with DOA, including several from Denmark, the United Kingdom, Germany, France, Cuba, Japan, and the United States, have genetic homogeneity in their linkage to the telomeric portion of the long arm of chromosome 3 (3q28-29). ${ }^{100,101,120-125}$ Between 30 and $90 \%$ of these families have been found to harbour over 60 different missence and nonsense mutations, deletions, and insertions in a gene within this region that has been designated the OPA1 gene. ${ }^{122-128}$ The product of the OPA1 gene is targeted to the mitochondria and appears to exert its function in mitochondrial biogenesis and stabilization of mitochondrial membrane integrity. ${ }^{122-124}$

Downregulation of the OPA1 leads to fragmentation of the mitochondrial network and dissipation of the mitochondrial membrane potential with cytochorme $c$ release and caspase-dependent apoptosis. ${ }^{129}$ These findings demonstrate the crucial role of mitochondria in retinal ganglion cell pathophysiology. ${ }^{124}$ Linkage analysis of patients with normal tension glaucoma has shown an association with polymorphisms of the OPA1 gene. ${ }^{130}$ Interestingly, there is a mutant strain of mice with dominantly inherited optic atrophy with variable expressivity. ${ }^{131}$ The mutation in these mice is located on the mouse chromosome 16, which is homologous to the human chromosome 3 .

\section{Other monosymptomatic hereditary optic neuropathies}

Compared to LHON and DOA, other monosymptomatic optic neuropathies are extremely rare. ${ }^{1}$ They include congenital recessive optic atrophy, ${ }^{132}$ apparent sex-linked optic atrophy, ${ }^{133,134}$ and possibly an autosomal recessive chiasmal optic neuropathy. ${ }^{135}$

\section{Hereditary optic atrophy with other consistent neurologic or systemic findings}

In some pedigrees with inherited optic neuropathies, certain neurologic or systemic manifestations are regularly observed. ${ }^{1}$ These include pedigrees with: autosomal dominant optic atrophy and deafness; autosomal dominant optic atrophy with hearing loss and ataxia; hereditary optic atrophy with hearing loss and polyneuropathy; autosomal recessive optic atrophy with hearing loss, spastic quadriplegia, mental deterioration and death (opticocochleodentate degeneration); opticoacoustic nerve atrophy with dementia; diabetes insipidus, diabetes mellitus, optic atrophy and deafness (DIDMOAD or Wolfram's syndrome); progressive encephalopathy with oedema, hypsarrhythmia and optic atrophy; and autosomal recessive complicated hereditary infantile optic atrophy (Behr's syndrome). The most common of these syndromes are Wolfram's syndrome and Behr's syndrome.

Since $1938,{ }^{136}$ about 300 cases of Wolfram's syndrome have been recorded, with a prevalence of one in 770000 in the United Kingdom. ${ }^{137-144}$ Most cases have been classified as sporadic or recessively inherited. The hallmark of all these cases is the association of juvenile diabetes mellitus and progressive visual loss with optic atrophy, almost always associated with diabetes insipidus, neurosensory hearing loss, or both (hence, the eponym DIDMOAD for diabetes insipidus, diabetes mellitus, optic atrophy, and deafness). The progression and development of this syndrome is variable.

Symptoms and signs of diabetes mellitus usually occur within the 1st or 2nd decade of life and usually precede the development of optic atrophy. In several cases, however, visual loss with optic atrophy was the first sign of the syndrome. In the early stages, visual acuity may be normal despite mild dyschromatopsia and optic atrophy. In later stages, visual loss becomes severe, usually worse than 20/200, suggesting progression. ${ }^{137,141}$ Visual fields show both generalized constriction and central scotomas. Optic atrophy is uniformly severe, and there may be mild to moderate cupping of the disc. 
The onset of hearing loss and of diabetes insipidus in this syndrome is equally variable. Both begin in the 1st or 2nd decade of life and may be quite severe. Atonia of the efferent urinary tract is present in $46-58 \%$ of patients and is associated with recurrent urinary tract infections and even fatal complications. ${ }^{138,139}$ Other systemic and neurologic abnormalities include ataxia, axial rigidity, seizures, startle myoclonus, tremor, gastrointestinal dysmotility, vestibular malfunction, central apnea, neurogenic upper airway collapse, ptosis, cataracts, pigmentary retinopathy, iritis, lacrimal hyposecretion, tonic pupil, ophthalmoplegia, convergence insufficiency, vertical gaze palsy, mental retardation, psychiatric abnormalities, nystagmus, short stature, primary gonadal atrophy, other endocrine abnormalities, anosmia, megaloblastic and sideroblastic anaemia, abnormal electroretinography, and elevated cerebrospinal fluid protein. ${ }^{137,139,140,143-145}$ Psychiatric disorders are also seen at an increased frequency among heterozygous carriers. ${ }^{146}$ Pathology and neuroimaging in some patients reveal widespread atrophic changes and suggest a diffuse neurodegenerative disorder, with particular involvement of the midbrain and pons. ${ }^{140,144,147}$ Median age at death is 30 years, most commonly due to central respiratory failure with brain-stem atrophy. ${ }^{139,148}$ When the syndrome is accompanied by anaemia, treatment with thiamine may ameliorate the anaemia and decrease the insulin requirement. ${ }^{149}$

Many of the associated abnormalities reported in Wolfram's syndrome are commonly encountered in patients with presumed mitochondrial diseases, especially those patients with the chronic progressive external ophthalmoplegia syndromes. ${ }^{150}$ This has led to the speculation that the Wolfram's phenotype may be nonspecific and reflect a wide array of underlying genetic defects in either the nuclear or mitochondrial genomes, with perhaps a unifying pathogenesis in underlying mitochondrial dysfunction. ${ }^{151,152}$ Polymeropoulos et al ${ }^{153}$ proposed localization of the Wolfram's gene to the short arm of chromosome 4 in several families with presumed autosomal recessive inheritance. This locus was further refined to chromosome 4p16.1 and accounts for many, but not all, DIDMOAD pedigrees. ${ }^{154,155}$ The gene responsible at this locus has been designated WFS1, in which multiple point mutations and deletions have been identified. ${ }^{155}$ Some of these mutations were subsequently found to be a common cause of inherited isolated lowfrequency hearing loss. ${ }^{156}$ In one report, the locus on chromosome 4p16 was proposed as a predisposing factor for the formation of multiple mtDNA deletions. ${ }^{157}$ DIDMOAD patients were also found to concentrate on two major mtDNA haplotypes that are also overrepresented among LHON patients. ${ }^{158}$ A phenotypic variant of Wolfram's syndrome with peptic ulcer disease and bleeding secondary to a platelet aggregation defect, but without diabetes insipidus, was noted in four consanguineous Jordanian families and linked to a second locus (WFS2) on chromosome $4 \mathrm{q} 22-24 .{ }^{143,159}$

In 1909, Behr ${ }^{160}$ described a syndrome of heredofamilial optic atrophy beginning in early childhood and associated with variable pyramidal tract signs, ataxia, mental retardation, urinary incontinence, and pes cavus. The syndrome has been reported in both sexes, ${ }^{161,162}$ and is believed to be autosomal recessively inherited. Visual loss usually manifests before age 10 years, is moderate to severe, and is frequently accompanied by nystagmus. Neuroimaging may demonstrate diffuse symmetric white matter abnormalities. In several Iraqi-Jewish pedigrees of Behr's syndrome, 3-methylglutaconic aciduria was identified, leading to mapping of the gene (designated OPA3) to chromosome 19q13.2-13.3. ${ }^{163-166}$ These patients had infantile optic atrophy and an early-onset extrapyramidal movement disorder dominated by chorea. Approximately half of the patients developed spastic paraparesis by the 2 nd decade, and the majority of affected individuals were female. Clinical findings in Behr's syndrome may be similar to those in cases of hereditary ataxia. Behr's syndrome is likely heterogeneous, reflecting different aetiologic and genetic factors. ${ }^{1}$

\section{Optic neuropathy as a manifestation of hereditary degenerative or developmental diseases}

Inherited diseases with primarily neurologic or systemic manifestations, such as the multisystem degenerations, can include optic atrophy among their signs, typically as a secondary and inconsistent finding. This category of disorders encompasses the hereditary ataxias, the hereditary polyneuropathies, the hereditary spastic paraplegias, the hereditary muscular dystrophies, storage diseases and other cerebral degenerations of childhood, and mitochondrial disorders other than LHON. ${ }^{1}$

Friedrich's ataxia is an autosomal recessive disorder linked to the long arm of chromosome 9 (9q13-q21) involving a GAA trinucleotide expansion in a gene coding for a protein called frataxin, which regulates iron levels in the mitochondria. ${ }^{167}$ The disease usually begins during the second decade of life and includes progressive ataxia, dysarthria, loss of joint position and vibratory sensation, absence of lower extremity tendon reflexes, and extensor plantar responses. Scoliosis, foot deformity, diabetes mellitus, and cardiac disease are common. Other manifestations include pes cavus, distal 
wasting, deafness, eye movement abnormalities consistent with abnormal cerebellar function, and optic atrophy. The course is progressive, with most patients unable to walk within 15 years of onset, and death from infectious or cardiac causes usually in the fourth or fifth decades. A later-onset, more slowly progressive form has also been described. Evidence of optic neuropathy is present in up to two-thirds of cases of Friedreich's ataxia, although severe visual loss is uncommon. ${ }^{168-174} \mathrm{~A}$ condition resembling Friedreich's ataxia associated with decreased vitamin $\mathrm{E}$ levels has been localized to chromosome 8, and also includes some patients with optic atrophy. ${ }^{175}$ Vitamin E supplementation of these patients may be efficacious early in the course of the disease.

The spinocerebellar ataxias (SCA), previously called olivopontocerebellar atrophy (OPCA) and autosomal dominant cerebellar ataxia (ADCA), comprise a group of hereditary ataxic disorders in which the ataxia is related more to degeneration of the cerebellum than the spinal cord. ${ }^{167,176}$ As of 2003, there were at least 23 different genetic loci for the SCAs (SCA1-SCA17). ${ }^{167}$ (George Wilmot, 2003, Personal Communication). The combination of SCA1 (chromosome 6p), SCA2 (chromosome 12q), SCA3 (chromosome 14q), SCA6 (chromosome 19p), and SCA7 (chromosome 3p) comprises approximately $80 \%$ of the autosomal dominant ataxias. ${ }^{167}$ Many of the SCAs are caused by mutations involving the expansion of a CAG trinucleotide repeat in the protein coding sequences of specific genes. Clinically, the SCAs are characterized by signs and symptoms attribuable to cerebellar degeneration and sometimes other neurologic dysfunction secondary to neuronal loss. Loss of vision is usually mild but may be a prominent symptom, occurring in association with constricted visual fields and diffuse optic atrophy. ${ }^{177}$ However, it is not clear in some cases whether the primary process is retinal with secondary optic atrophy or primarily involving the optic nerve. Detailed analysis of the prevalence of optic atrophy among the different genotypes now associated with the SCAs has not been performed. Prior to genetic analysis, Harding ${ }^{178}$ categorized the ADCAs into four types, with only the first type having individuals with primary optic atrophy (approximately $30 \%$ of cases). We now know that ADCA type I encompasses multiple genetic loci, including those pedigrees now classified genetically as SCA1, SCA2, SCA3, and probably SCA4 and SCA5. Initial studies suggest that patients with the SCA2 genotype do not exhibit optic atrophy, ${ }^{179}$ whereas the SCA3 patients may have optic atrophy, especially if their ataxia is severe, and there are several SCA1 families with optic atrophy. ${ }^{177}$ SCA7 is specifically associated with retinal degeneration.
Among the hereditary polyneuropathies, CharcotMarie-Tooth disease (CMT) encompasses a group of heredofamilial disorders characterized by progressive muscular weakness and atrophy that begins during the first two decades of life. ${ }^{167}$ This group of hereditary polyneuropathies accounts for $90 \%$ of all hereditary neuropathies, with the prevalence in the United States being about 40 per 100000 . Most forms of CMT begin between the ages of 2 and 15 years, and the first signs may be pes cavus, foot deformities, or scoliosis. There is slowly progressive weakness and wasting, first of the feet and legs, and then of the hands. Motor symptoms predominate over sensory abnormalities. As of 2002, causative mutations for the hereditary peripheral neuropathies have been identified in 17 different genes. ${ }^{180}$ Inheritance is most commonly autosomal dominant, although autosomal recessive and also X-linked forms occur. Numerous patients with CMT and optic atrophy have been reported. ${ }^{181,182}$ Associated visual loss, if present, is usually mild. However, taking into account both electrophysiologic and clinical data, up to $75 \%$ of patients with CMT have some afferent visual pathway dysfunction, demonstrating that subclinical optic neuropathy may occur in a high proportion of patients with CMT. ${ }^{183}$ Pedigrees specifically designated CMT type 6 show a regular association of CMT and optic atrophy. ${ }^{181,182}$ This type of CMT is as yet genetically unspecified and may prove genetically heterogeneous. ${ }^{181}$

Familial dysautonomia (Riley-Day syndrome) is an autosomal recessive disease that almost exclusively affects Ashkenazi Jews. Abnormalities of the peripheral nervous system cause the clinical manifestations of sensory and autonomic dysfunction. Optic atrophy is very common in patients with familial dysautonomia, usually noted after the first decade of life ${ }^{184,185}$ However, in most cases, early mortality from the disease probably precludes the later development of optic atrophy. ${ }^{184}$

The hereditary spastic paraplegias (Strumpell-Lorrain disease) are autosomal dominant disorders characterized by progressive spasticity of the lower limbs and pathological reflexes with degeneration or demyelination of the cortico-spinal system and of the spinocerebellar system. Optic neuropathies with visual acuities ranging from $20 / 20$ to $20 / 200$ have been reported in a small number of patients with this disease. ${ }^{186}$

One of the most common of the hereditary muscular dystrophies, myotonic dystrophy is an autosomal dominant disorder with a prevalence of 1 in 20000 , characterized by progressive myopathy, ptosis, cataracts, cardiomyopathy with conduction defects, frontal balding, bifacial weakness, and diabetes mellitus. Most patients with myotonic dystrophy have an expansion of a CTG repeat in a protein kinase gene on chromosome 
19q13.3. Less common ophthalmic manifestations include external ophthalmoplegia, pigmentary retinopathy, and optic atrophy. ${ }^{167}$

There are more than 100 inherited metabolic diseases and as yet undefined genetic syndromes with ocular manifestations, including optic atrophy. These include the storage diseases such as the mucopolysaccharidoses and the lipidoses, the hereditary leukodystrophies, including Krabbe's disease, mucosulphatidosis, metachromatic leukodystrophy, adrenoleukodystrophy and adrenomyeloneuropathy, Zellweger syndrome, Pelizeus-Merzbacher disease, infantile neuroaxonal dystrophy, Hallervorden-Spatz disease, Menkes syndrome, Canavan's disease, Cockayne syndrome, cerebro-oculo-facio-skeletal syndrome, Smith-LemliOpitz syndrome, Allgrove syndrome, and GAPO (growth retardation, alopecia, pseudoanodontia, and optic atrophy) syndrome. ${ }^{1}$

The prototype for a mitochondrial abnormality resulting in optic nerve dysfunction is, of course, LHON with its classically isolated optic nerve involvement and its causal relationship to mitochondrial DNA point mutations (see above). Additionally, Kjer's dominant optic atrophy likely results from perturbations of mitochondrial function secondary to abnormalities in a nuclear gene whose product is destined for the mitochondria. Other multisystem hereditary disorders with prominent optic nerve involvement, such as Wolfram's syndrome, may also prove to have a final common pathway in mitochondrial dysfunction. Indeed, the seemed selective vulnerability of the ganglion cell or its axon to both hereditary and acquired mitochondrial abnormalities suggests a possible common pathophysiology for these disorders. ${ }^{187}$ Given this relative selective involvement of the optic nerve in these disorders, however, it is somewhat surprising that other mitochondrial disorders do not regularly manifest optic neuropathies.

The subacute necrotizing encephalomyelopathy of Leigh results from multiple different biochemical defects that all impair cerebral oxidative metabolism. ${ }^{1,2,188}$ This disorder may be inherited in an autosomal recessive, $X$-linked, or maternal pattern, depending on the genetic defect. The onset of symptoms is typically between the ages of 2 months and 6 years, and consists of progressive deterioration of brainstem functions, ataxia, seizures, peripheral neuropathy, intellectual deterioration, impaired hearing and poor vision. Visual loss may be secondary to optic atrophy or retinal degeneration. Many cases have optic nerves with extensive atrophy on pathologic examination. ${ }^{189}$ The syndrome of Leigh is likely a nonspecific phenotypic response to certain abnormalities of mitochondrial energy production.

Other presumed mitochondrial disorders of both nuclear and mitochondrial genomic origins may manifest optic atrophy as a secondary clinical feature, often a variable manifestation of the disease. ${ }^{2,190}$ Examples include cases of MERRF, MELAS, and chronic progressive external ophthalmoplegia, both with and without the full Kearns-Sayre phenotype. ${ }^{1}$ The other, more constant, phenotypic characteristics of all of these mitochondrial disorders distinguish them from diseases such as Leber's optic neuropathy in which visual loss from optic nerve dysfunction is the primary manifestation of the disorder.

\section{Acknowledgements}

This study was supported in part by a departmental grant (Department of Ophthalmology) from the Research to Prevent Blindness, Inc., New York, New York, and by core Grant P30-EY06360 (Department of Ophthalmology) from the National Institutes of Health, Bethesda, Maryland. Dr Newman is a recipient of a Research to Prevent Blindness Lew R Wasserman Merit Award.

\section{References}

1 Newman NJ. Hereditary optic neuropathies. In: Miller NR, Newman NJ (eds). Walsh \& Hoyt Clinical NeuroOphthalmology, Vol. 1, 5th edn. Williams \& Wilkins: Baltimore, 1999 pp 741-773.

2 Biousse V, Newman NJ. Hereditary optic neuropathies. Ophthalmol Clin NA 2001; 14: 547-568.

3 Leber T. Über hereditare und congenitalangelegte sehnervenleiden. Albrecht von Graefe's Arch Ophthalmol 1871; 17: 249-291.

4 von Graefe A. Ein ungewohnlicher fall von hereditare amaurose. Arch Ophthalmol 1858; 4: 266-268.

5 Asseman R. La Maladie de Leber Etude Clinique et Genetique à Propos de 86 Cas Examines. Thèse, Universitaire de Lille, 1958.

6 Van Senus AHC. Leber's disease in the Netherlands. Doc Ophthalmol 1963; 17: 1-163.

7 Newman NJ, Lott MT, Wallace DC. The clinical characteristics of pedigrees of Leber's hereditary optic neuropathy with the 11778 mutation. Am J Ophthalmol 1991; 111: 750-762.

8 Mackey D, Buttery RG. Leber hereditary optic neuropathy in Australia. Aust N Z J Ophthalmol 1992; 20: 177-184.

9 Riordan-Eva P, Sanders MD, Govan GG, Sweeney MC, DaCosta J, Harding AE. The clinical features of Leber's hereditary optic neuropathy defined by the presence of a pathogenic mitochondrial DNA mutation. Brain 1995; 118: 319-337.

10 Hotta Y, Fujiki K, Hayakawa M, Nakajima A, Kanai A, Mashima $Y$ et al. Clinical features of Japanese Leber's hereditary optic neuropathy with 11778 mutation of mitochondrial DNA. Jpn J Ophthalmol 1995; 39: 96-108.

11 Nikoskelainen EK, Huoponen K, Juvonen V, Lamminen T, Nummelin K, Savontaus ML. Ophthalmologic findings in Leber hereditary optic neuropathy, with special reference to mtDNA mutations. Ophthalmology 1996; 103: 504-514.

12 Yamada K, Oguchi Y, Hotta Y, Nakamura M, Isashiki Y, Mashima Y. Multicenter study on the frequency of three primary mutations of mitochondrial DNA in Japanese 
pedigrees with Leber's hereditary optic neuropathy: comparison with American and British counterparts. Neuro-ophthalmology 1999; 22: 187-193.

13 Sadun AA, Carelli V, Salomao SR, Berezovsky A, Quiros P, Sadun $\mathrm{F}$ et al. A very large Brazilian pedigree with 11778 Leber's hereditary optic neuropathy. Trans Am Ophthalmol Soc 2002; 100: 169-180.

14 Yen M-Y, Wang A-G, Chang W-L, Hsu W-M, Liu J-H, Wei Y-H. Leber's hereditary optic neuropathy-the spectrum of mitochondrial DNA mutations in Chinese patients. Jpn J Ophthalmol 2002; 46: 45-51.

15 Wallace DC, Singh G, Lott MT, Hodge JA, Schurr TG, Lezza AM et al. Mitochondrial DNA mutation associated with Leber's hereditary optic neuropathy. Science 1988; 242 1427-1430.

16 Newman NJ. Leber's hereditary optic neuropathy: new genetic considerations. Arch Neurol 1993; 50: 540-548.

17 Mackey DA, Oostra R-J, Rosenberg T, Nikoskelainen E, Bronte-Stewart J, Poulton J et al. Primary pathogenic mtDNA mutations in multigeneration pedigrees with Leber hereditary optic neuropathy. (Letter). Am J Hum Genet 1996; 59: 481-485.

18 Chinnery PF, Brown DT, Andrews RM, Singh-Kler R, Riordan-Eva P, Lindley J et al. The mitochondrial ND6 gene is a hot spot for mutations that cause Leber's hereditary optic neuropathy. Brain 2001; 124: 209-218.

19 Huoponen, K. Leber hereditary optic neuropathy: clinical and molecular genetic findings. Neurogenetics 2001 3: 119-125.

20 Man PYW, Turnbull DM, Chinnery PF. Leber hereditary optic neuropathy. J Med Genet 2002; 39: 162-169.

21 Chinnery PF, Johnson MA, Wardell TM, Singh-Kler R, Hayes C, Brown DT et al. The epidemiology of pathogenic mitochondrial DNA mutations. Ann Neurol 2000; 48 188-193.

22 Man PYW, Griffiths PG, Brown DT. The epidemiology of Leber hereditary optic neuropathy in the north east of England. Am J Hum Genet 2003; 72: 333-339.

23 Mackey DA. Epidemiology of Leber's hereditary optic neuropathy in Australia. Clin Neurosci 1994; 2: 162-164.

24 Mackey DA. Three subgroups of patients from the United Kingdom with Leber hereditary optic neuropathy. Eye 1994; 8: 431-436.

25 Chan C, Mackey DA, Byrne E. Sporadic Leber hereditary optic neuropathy in Australia and New Zealand. Aust N Z I Ophthalmol 1996; 24: 7-14.

26 Nikoskelainen EK, Savontaus ML, Wanne OP, Katila MJ, Nummelin KU. Leber's hereditary optic neuroretinopathy, a maternally inherited disease. A genealogic study in four pedigrees. Arch Ophthalmol 1987; 105: 665-671.

27 Harding AE, Sweeney MG, Govan GG, Riordan-Eva P. Pedigree analysis in Leber hereditary optic neuropathy families with a pathogenic mtDNA mutation. Am J Hum Genet 1995; 57: 77-86.

28 Mackey D, Howell N. Tobacco amblyopia [Letter]. Am J Ophthalmol 1994; 117: 817-818.

29 Carroll WM, Mastaglia FL. Leber's optic neuropathy. A clinical and visual evoked potential study of affected and asymptomatic members of a six generation family. Brain 1979; 102: 559-580.

30 Wakakura M, Yokoe J. Evidence for preserved direct pupillary light response in Leber's hereditary optic neuropathy. Br J Ophthalmol 1995; 79: 442-446.
31 Jacobson DM, Stone EM, Miller NR, Pollock SC, Fletcher WA, McNussen PJ et al. Relative afferent papillary defects in patients with Leber hereditary optic neuropathy and unilateral visual loss. Am J Ophthalmol 1998; 126: 291-295.

32 Raaf JE, Bair HL. Leber's disease: report of four cases in one family. Am J Ophthalmol 1938; 21: 384-389.

33 Weiner NC, Newman NJ, Lessell S, Johns DR, Lott MT, Wallace DC. Atypical Leber's hereditary optic neuropathy with molecular confirmation. Arch Neurol 1993; 50: 470-473.

34 Smith JL, Hoyt WF, Susac JO. Ocular fundus in acute Leber optic neuropathy. Arch Ophthalmol 1973; 90: 349-354.

35 Stone EM, Newman NJ, Miller NR, Johns DR, Lott MT, Wallace DC. Visual recovery in patients with Leber's hereditary optic neuropathy and the 11778 mutation. J Clin Neuro-Ophthalmol 1992; 12: 10-14.

36 Brunette JR, Bernier G. Study of a family of Leber's optic atrophy with recuperation. In: Brunette JR, Barbeau A (eds). Progress in Neuro-Ophthalmology. Excerpta Medica: Amsterdam, 1969 pp 91-97.

37 Nikoskelainen E, Wanne O, Dahl M. Pre-excitation syndrome and Leber's hereditary optic neuroretinopathy. Lancet 1985; 1: 696.

38 Ortiz RG, Newman NJ, Manoukian S, Diesenhouse MC, Lott MT, Wallace DC. Optic disk cupping and electrocardiographic abnormalities in an American pedigree with Leber's hereditary optic neuropathy. Am J Ophthalmol 1992; 113: 561-566.

39 Nikoskelainen EK, Savontaus ML, Huoponen J, Antila K, Hartiala J. Pre-excitation syndrome in Leber's hereditary optic neuropathy. Lancet 1994; 344: 857-858.

40 Mashima Y, Kigasawa K, Hasegawa H, Tani M, Oguchi Y. High incidence of pre-excitation syndrome in Japanese families with Leber's hereditary optic neuropathy. Clin Genet 1996; 50: 535-537.

41 Finsterer J, Stollberger C, Kopsa W, Jaksch M. WolffParkinson-White syndrome and isolated left ventricular abnormal trabeculation as a manifestation of Leber's hereditary optic neuropathy. Can J Cardiol 2001; 17: 464-466.

42 Nikoskelainen EK, Marttila RJ, Huoponen K, Juvonen V, Lamminen T, Sonninen P et al. Leber's 'plus': neurological abnormalities in patients with Leber's hereditary optic neuropathy. J Neurol Neurosurg Psychiatry 1995; 59: 160-164.

43 Chalmers RM, Harding AE. A case-control study of Leber's hereditary optic neuropathy. Brain 1996; 119: 1481-1486.

44 Wallace DC. A new manifestation of Leber's disease and a new explanation for the agency responsible for its unusual pattern of inheritance. Brain 1970; 93: 121-132.

45 Novotny EJ, Singh G, Wallace DC, Dorfman LJ, Louis A, Sogg RL. Leber's disease and dystonia. A mitochondrial disease. Neurology 1986; 36: 1053-1060.

46 Marsden DC, Lang AE, Quinn NP, McDonald WI, Abdallat A, Nimri S. Familial dystonia and visual failure with striatal CT lucencies. J Neurol Neurosurg Psychiatry 1986; 49: 500-509.

47 Bruyn GW, Vielvoye GJ, Went LN. Hereditary spastic dystonia: a new mitochondrial encephalopathy? Putaminal necrosis as a diagnostic sign. J Neurol Sci 1991; 103: 195-202.

48 Leuzzi V, Bertini E, De Negri AM, Gallucci M, Garavaglia B. Bilateral striatal necrosis, dystonia and optic atrophy in two siblings. J Neurol Neurosurg Psychiatry 1992; 55: 16-19. 
49 De Vries DD, Went LN, Bruyn GW, Scholte HR, Hofstra RM, Bolhuis PA et al. Genetic and biochemical impairment of mitochondrial complex I activity in a family with Leber hereditary optic neuropathy and hereditary spastic dystonia. Am J Hum Genet 1996; 58: 703-711.

50 Hanemann CO, Hefter H, Schlaug G, Seitz RJ, Freund HJ, Benecke R. Characterization of basal ganglia dysfunction in Leber 'plus' disease. J Neurol 1996; 243: 297-300.

51 Riggs JE, Ellis BD, Hogg JP, Al-Azzaz A, Schochet Jr SS. Acute periaqueductal syndrome associated with the G11778A mitochondrial DNA mutation. Neurology 2001; 56: 570-571.

52 Sadler M, Wiles CM, Stoodley N, Linnane SJ, Smith AP. Ondine's curse in a woman with Leber's hereditary optic neuropathy. J Neurol Neurosurg Psychiatry 2002; 73: 347-348.

53 Funalot B, Reynier P, Vighetto A, Ranoux D, Bonnefont J-P, Godinot $\mathrm{C}$ et al. Leigh-like encephalopathy complicating Leber's hereditary optic neuropathy. Ann Neurol 2002; 52: 374-377.

54 Harding AE, Sweeney MG, Miller DH, Mumford CJ, Kellar-Wood H, Menard D et al. Occurrance of a multiple sclerosis-like illness in women who have a Leber's hereditary optic Neuropathy Mitochondrial DNA mutation. Brain 1992; 115: 979-989.

55 Bhatti MT, Newman NJ. A multiple sclerosis-like illness in a man harboring the mtDNA 14484 mutation. J Neuroophthalmol 1999; 19: 28-33.

56 Kellar-Wood H, Robertson N, Govan GG, Compston DA, Harding AE. Leber's hereditary optic neuropathy mitochondrial DNA mutations in multiple sclerosis. Ann Neurol 1994; 36: 109-112.

57 Leuzzi V, Carducci C, Lanza M, Salvetti M, Ristori G, DiGiovanni $\mathrm{S}$ et al. LHON mutations in Italian patients affected by multiple sclerosis. Acta Neurol Scand 1997; 96: $145-148$.

58 Wakakura M, Mogi A, Ichibe Y, Okada K, Hasebe H. Leber's hereditary optic neuropathy triggered by optic neuritis. Neuro-ophthalmology 1996; 16: 337-341.

59 Kermode AG, Moseley IF, Kendall BE, Miller DH, MacManus DG, McDonald WI. Magnetic resonance imaging in Leber's optic neuropathy. J Neurol Neurosurg Psychiatry 1989; 52: 671-674.

60 Lev D, Yanoov-Sharav M, Watemberg N, Leshinsky-Silver E, Lerman-Sagie T. White matter abnormalities in Leber's hereditary optic neuropathy due to the 3460 mitochondrial DNA mutation. Eur J Paediatr Neurol 2002; 6: 121-123.

61 Smith JL, Tse DT, Byrne SF, Johns DR, Stone EM. Optic nerve sheath distention in Leber's optic neuropathy and the significance of the 'Wallace mutation'. J Clin NeuroOphthalmol 1990; 10: 231-238.

62 Wilson DR, Kline LB. Leber's hereditary optic neuropathy with bilateral distended optic nerve sheaths. J Clin NeuroOphthalmol 1992; 12: 73-74.

63 Dotti MT, Caputo N, Signorini E, Federico A. Magnetic resonance imaging findings in Leber's hereditary optic neuropathy. Eur Neurol 1992; 32: 17-19.

64 Mashima Y, Oshitari K, Imamura Y, Momoshima S, Shiga $\mathrm{H}$, Oguchi Y. Orbital high resolution magnetic resonance imaging with fast spin echo in the acute stage of Leber's hereditary optic neuropathy. J Neurol Neurosurg Psychiatry 1998; 64: 124-127.

65 Inglese M, Rovaris M, Bianchi S, LaMantia L, Mancardi GL, Ghezzi A et al. Magnetic resonance imaging, magnetization transfer imaging, and diffusion weighted imaging correlates of optic nerve, brain, and cervical cord damage in Leber's hereditary optic neuropathy. J Neurol Neurosurg Psychiatry 2001; 70: 444-449.

66 Vaphiades MS, Newman NJ. Optic nerve enhancement on orbital magnetic resonance imaging in Leber's hereditary optic neuropathy. J Neuro-ophthalmol 1999; 19: 238-239.

67 Vaphiades MS, Phillips PH, Turbin RE. Optic nerve and chiasmal enhancement in Leber hereditary optic neuropathy. J Neuro-ophthalmol 2003; 23: 104-105.

68 Phillips PH, Vaphiades M, Glasier CM, Gray LG, Lee AG. Chiasmal enlargement and optic nerve enhancement on magnetic resonance imaging in Leber hereditary optic neuropathy. Arch Ophthalmol 2003; 121: 577-579.

69 Kerrison JB, Howell N, Miller NR, Hirst L, Green WR. Leber hereditary optic neuropathy: electron microscopy and molecular genetic analysis of a case. Ophthalmology 1995; 102: 1509-1516.

70 Saadati HG, Hsu HY, Heller KB, Sadun AA. A histopathologic and morphometric differentiation of nerves in optic nerve hypoplasia and Leber hereditary optic neuropathy. Arch Ophthalmol 1998; 116: 911-916.

71 Sadun AA, Win P, Ross-Cisneros F, Walker S, Carelli V. Leber's hereditary optic neuropathy differentially affects smaller axons in the optic nerve. Trans Am Ophthalmol Soc 2000; 98: 1-13.

72 Newman NJ. From genotype to phenotype in Leber hereditary optic neuropathy: still more questions than answers. J Neuro-ophthalmol 2002; 22: 257-261.

73 Macmillan C, Johns TA, Fu K, Shoubridge EA. Predominance of the T14484C mutation in FrenchCanadian families with Leber hereditary optic neuropathy is due to a founder effect. Am J Hum Genet 2000; 66: 332-335.

74 Carelli V, Rengo C, Scozzari R, Valentino ML, Carrara F, Zeviani $\mathrm{M}$ et al. mtDNA haplotypes allow genealogical aggregation of apparently unrelated LHON pedigrees. Neurology 2003; 60(Suppl): A3.

75 Biousse V, Brown MD, Newman NJ, Allen JC, Rosenfeld J, Meola G et al. De novo 14484 mitochondrial DNA mutation in monozygotic twins discordant for Leber's hereditary optic neuropathy. Neurology 1997; 49: 1136-1138.

76 Chinnery PF, Andrews RM, Turnbull DM, Howell N. Leber hereditary optic neuropathy: does heteroplasmy influence the inheritance and expression of the G11778A mitochondrial DNA mutation? Am J Med Genet 2001; 98: 235-243.

77 Oostra RJ, Bolhuis PA, Wijburg FA, Zorn-Ende G, BleekerWagemakers EM. Leber's hereditary optic neuropathy. Correlations between mitochondrial genotype and visual outcome. J Med Genet 1994; 31: 280-286.

78 Brown MD, Allen JC, VanStavern GP, Newman NJ, Wallace DC. Clinical, genetic, and biochemical characterization of a Leber hereditary optic neuropathy family containing both the 11778 and 14484 primary mutations. Am J Med Genet 2001; 104: 331-338.

79 Howell N, Miller NR, Mackey DA, Arnold A, Herrnstadt $\mathrm{C}$, Williams IM et al. Lightning strikes twice: Leber hereditary optic neuropathy families with two pathogenic mtDNA mutations. J Neuro-ophthalmol 2002; 22: 262-269.

80 Brown MD, Starikovskaya E, Derbeneva O, Hosseini S, Allen JC, Mikhailovskaya IE et al. The role of mtDNA background in disease expression: a new primary LHON 
mutation associated with Western Eurasian haplogroup. J Hum Genet 2002; 110: 130-138.

81 Trounce I, Byrne E, Marzuki S. Decline in skeletal muscle mitrochondrial respiratory chain function: possible factor in aging. Lancet 1989; 1: 637-639.

82 Newman NJ, Torroni A, Brown MD, Lott MT, Fernandez MM, Wallace DC. Epidemic neuropathy in Cuba not associated with mitochondrial DNA mutations found in Leber's hereditary optic neuropathy patients. Am J Ophthalmol 1994; 118: 158-168.

83 Kerrison JB, Miller NR, Hsu F-C, Beaty TH, Maumenee IH, Smith $\mathrm{KH}$ et al. A case-control study of tobacco and alcohol consumption in Leber hereditary optic neuropathy. Am J Ophthalmol 2000; 130: 803-812.

84 Dotti MT, Plewnia K, Cardaioli E, Manneschi L, Rufa A, Alema $\mathrm{G}$ et al. A case of ethambutol-induced optic neuropathy harbouring the primary mitochondrial LHON mutation at nt 11778. J Neurol 1998; 245: 302-303.

85 DeMarinis M. Optic neuropathy after treatment with anti-tuberculous drugs in a subject with Leber's hereditary optic neuropathy mutation. J Neurol 2001; 248: 818-819.

86 Luzhansky JZ, Pierce AB, Hoy JF, Hall AJ, Anthony JH. Leber's hereditary optic neuropathy in the setting of nucleoside analogue toxicity. AIDS 2001; 15: 1588-1589.

87 Shaikh S, Ta C, Basham AA, Mansour S. Leber hereditary optic neuropathy associated with antiretroviral therapy for human immunodeficiency virus infection. Am J Ophthalmol 2001; 131: 143-145.

88 Warner JE, Ries KM. Optic neuropathy in a patient with AIDS. J Neuro-ophthalmol 2001; 21: 92-94.

89 Howell N. Leber hereditary optic neuropathy: respiratory chain dysfunction and degeneration of the optic nerve. Vision Res 1998; 38: 1495-1504.

90 Schapira AH. Mitochondrial disorders: an overview. J Bioenergetics Biomemb 1997; 29: 105-107.

91 Schon EA, Bonilla E, DiMauro S. Mitochondrial DNA mutations and pathogenesis. J Bioenergetics Biomembranes 1997; 29: 131-149.

92 Qi X, Lewin AS, Hauswirth WW, Guy J. Suppression of complex I gene expression induces optic neuropathy. Ann Neurol 2003; 53: 198-205.

93 Imachi J. Neuro-surgical treatment of Leber's optic atrophy and its pathogenetic relationship to arachnoiditis. In: Brunette JR, Barbeau A (eds). Progress in Ophthalmology (Proceedings of the Second International Congress of NeuroGenetics and Neuro-Ophthalmology), Vol. 2. Excerpta Medica: Amsterdam, $1967 \mathrm{p} 121$.

94 Imachi J, Nishizaki K. The patients of Leber's optic atrophy should be treated neuro-surgically. Nippon Ganka Kiyo Jpn 1970; 21: 209-217.

95 Geromel V, Darin N, Chretien D, Benit P, DeLonlay P, Rotig A et al. Coenzyme $\mathrm{Q}(10)$ and idebenone in the therapy of respiratory chain diseases: rationale and comparative benefits. Mol Genet Metab 2002; 77: 21.

96 Mashima Y, Kigasawa K, Wakakura M, Oguchi Y. Do idebenon and vitamin therapy shorten the time to achieve visual recover in Leber hereditary optic neuropathy? J Neuro-ophthalmol 2000; 20: 166-170.

97 Yoles E, Wheeler LA, Schwartz M. Alpha-2-adenoreceptor agonists are neuroprotective in a rat model of optic nerve degeneration. Invest Ophthalmol Vis Sci 1999; 40: 65-73.

98 Guy J, Qi X, Pallotti F, Schon EA, Manfredi G, Carelli V et al. Rescue of a mitochondrial deficiency causing Leber hereditary optic neuropathy. Ann Neurol 2002; 52: 534-542.

99 Larsson NG. Leber's hereditary optic neuropathy: a nuclear solution of a mitochondrial problem. Ann Neurol 2002; 52: 529-530.

100 Eiberg H, Kjer B, Kjer P, Rosenberg T. Dominant optic atrophy (OPA1) mapped to chromosome $3 q$ region. I. Linkage analysis. Hum Mol Genet 1994; 3: 977-980.

101 Kjer B, Eiberg H, Kjer P, Rosenberg T. Dominant optic atrophy mapped to chromosome $3 \mathrm{q}$ region. II. Clinical and epidemiological aspects. Acta Ophthal Scand 1996; 74: 3-7.

102 Kjer P. Infantile optic atrophy with dominant mode of inheritance. A clinical and genetic study of 19 Danish families. Acta Ophthalmol 1959; 37(suppl. 54).

103 Kjer P. Hereditary infantile optic atrophy with dominant transmission (preliminary report). Dan Med Bull 1956; 3: 135-141.

104 Smith DP. Diagnostic criteria in dominantly inherited juvenile optic atrophy: a report of three new families. Am J Optom Physiol Opt 1972; 49: 183-200.

105 Johnston PB, Gaster RN, Smith VC, Tripathi RC. A clinicopathologic study of autosomal dominant optic atrophy. Am J Ophthalmol 1979; 88: 868-875.

106 Kline LB, Glaser JS. Dominant optic atrophy: The clinical profile. Arch Ophthalmol 1979; 97: 1680-1686.

107 Hoyt CS. Autosomal dominant optic atrophy: a spectrum of disability. Ophthalmology 1980; 87: 245-251.

108 Elliott D, Traboulsi EI, Maumenee IH. Visual prognosis in autosomal dominant optic atrophy (Kjer type). Am J Ophthalmol 1993; 115: 360-367.

109 Brown Jr J, Fingert J, Taylor CM, Lake M, Sheffield VC, Stone EM. Clinical and genetic analysis of a family affected with dominant optic atrophy (OPA1). Arch Ophthalmol 1997; 115: 95-99.

110 Johnston RL, Burdon MA, Spalton DJ, Bryant SP, Behnam JT, Seller MJ. Dominant optic atrophy, Kjer type. Arch Ophthalmol 1997; 115: 100-103.

111 Votruba M, Fitzke FW, Holder GE, Carter A, Bhattacharya SS, Moore AT. Clinical features in affected individuals from 21 pedigrees with dominant optic atrophy. Arch Ophthalmol 1998; 116: 351-358.

112 Kerrison JB, Arnould VJ, Ferraz Sallum JM, Vagefi MR, Barmada MM, Li Y et al. Genetic heterogeneity of dominant optic atrophy, Kjer type. Arch Ophthalmol 1999; 117: 805-810.

113 Johnston RL, Seller MJ, Behnam JT, Burdon MA, Spalton DJ. Dominant optic atrophy. Refining the clinical diagnostic criteria in light of genetic linkage studies. Ophthalmology 1999; 106: 123-128.

114 Smith DP. The assessment of acquired dyschromatopsia and clinical investigation of the acquired tritan defect in dominantly inherited juvenile atrophy. Am J Optom Physiol Opt 1972; 49: 574-588.

115 Votruba M, Thiselton D, Battacharya SS. Optic disc morphology of patients with OPA1 autosomal dominant optic atrophy. Br J Ophthalmol 2003; 87: 48-53.

116 Fournier AV, Damji KF, Epstein DL, Pollock SC. Disc excavation in dominant optic atrophy. Differentiation from normal tension glaucoma. Ophthalmology 2001; 108: 1595-1602.

117 Harding GFA, Crews SJ, Pitts SM. Psychophysical and visual evoked potential findings in hereditary optic atrophy. Trans Ophthalmol Soc UK 1979; 99: 96-102. 
118 Del Porto G, Vingolo EM, Steindl K, Forte R, Iannaccone A, Rispoli $\mathrm{E}$ et al. Clinical heterogeneity of dominant optic atrophy: the contribution of visual function investigations to diagnosis. Graefe's Arch Clin Exp Ophthalmol 1994; 32: 717-727.

119 Kivlin JD, Lovrien EW, Bishop DT, Maumenee IH. Linkage analysis in dominant optic atrophy. Am J Hum Genet 1983; 35: 1190-1195.

120 Lunkes A, Hartung AU, Magarino C, Rodriguez M, Palmero A, Rodriguez L et al. Refinement of the OPAI gene locus on chromosome $3 q 28-q 29$ to a region of $2-8 \mathrm{cM}$, in one Cuban pedigree with autosomal dominant optic atrophy type Kjer. Am J Hum Genet 1995; 57: 968-970.

121 Jonasdottir A, Eiberg H, Kjer B, Kjer P, Rosenberg T. Refinement of the dominant optic atrophy locus (OPA1) to a 1.4-cM interval on chromosome 3q28-3q29, within a 3-Mb YAC contig. Hum Genet 1997; 99: 115-120.

122 Delettre C, Lenaers G, Griffoin J-M, Gigarel N, Lorenzo C, Belenguer $P$ et al. Nuclear gene OPA1, encoding a mitochondrial dynamin-related protein, is mutated in dominant optic atrophy. Nature Genet 2000; 26: 207-210.

123 Alexander C, Votruba M, Pesch UEA, Thiselton DL, Mayer $\mathrm{S}$, Moore A et al. OPA1, encoding a dynamin-related GTPase, is mutated in autosomal dominant optic atrophy linked to chromosome 3q28. Nature Genet 2000; 26: 211-215.

124 Delettre C, Lenaers G, Pelloquin L, Belenguer P, Hamel CP. OPA1 (Kjer type) dominant optic atrophy: a novel mitochondrial disease. Mol Genet Metab 2002; 75: 97-107.

125 Shimizu S, Mori N, Kishi M, Sugata H, Tsuda A, Kubota N. A novel mutation in the OPA1Gene in a Japanese patient with optic atrophy. Am J Ophthalmol 2003; 135: 256-257.

126 Pesch UE, Leo-Kottler B, Mayer S, Jurklies B, Kellner U, Apfelstedt-Sylla E et al. OPA1 mutations in patients with autosomal dominant optic atrophy and evidence for semidominant inheritance. Hum Mol Genet 2001; 10: 1359-1368.

127 Toomes C, Marchbank NJ, Mackey DA, Craig JE, Newbury-Ecob RA, Bennett CP et al. Spectrum, frequency and penetrance of OPA1 mutations in dominant optic atrophy. Hum Mol Genet 2001; 10: 1369-1378.

128 Marchbank NJ, Craig JE, Leek JP, Toohey M, Churchill AJ, Markham AF et al. Deletion of the OPA1 gene in a dominant optic atrophy family: evidence that haploinsufficiency is the cause of disease. J Med Genet 2002; 39: e47.

129 Olichon A, Baricault L, Gas N, Guillou E, Valette A, Belenguer $\mathrm{P}$ et al. Loss of OPA1 perturbates the mitochondrial inner membrane structure and integrity, leading to cytochrome c release and apoptosis. J Biol Chem 2003; 278: 7743-7746.

130 Aung T, Okada K, Poinoosawmy D, Membrey L, Brice G, Child AH et al. The phenotype of normal tension glaucoma patients with and without OPA1 polymorphisms. $\mathrm{Br}$ J Ophthalmol 2003; 87: 49-152.

131 Rice DS, Williams RW, Ward-Bailey P, Johnson KR, Harris BS, Davisson MT et al. Mapping the Bst mutation on mouse chromosome 16: a model for human optic atrophy. Mamm Genome 1995; 6: 546-548.

132 Waardenburg PJ. Different types of hereditary optic atrophy. Acta Genet Statist Med 1957; 7: 287-290.

133 Went LN, De Vries-De Mol EC, Voklker-Dieben HJ. A family with apparently sex-linked optic atrophy. J Med Genet 1975; 12: 94-98.

134 Assink JJM, Tijmes NT, ten Brink JB, Oostra R-J, Riemslag FC, deJong PTVM et al. A gene for X-linked optic atrophy is closely linked to the Xp11.4-Xp11.2 region of the $\mathrm{X}$ chromosome. Am J Hum Genet 1997; 61: 934-939.

135 Pomeranz HD, Lessell S. A hereditary chiasmal optic neuropathy. Arch Ophthalmol 1999; 117: 128-131.

136 Wolfram DJ. Diabetes mellitus and simple optic atrophy among siblings. Mayo Clin Proc 1938; 13: 715-717.

137 Lessell S, Rosman NP. Juvenile diabetes mellitus and optic atrophy. Arch Neurol 1977; 34: 759-765.

138 Dreyer M, Rudiger HW, Bujara K, Herberhold C, Kuhnau $\mathrm{J}$, Maack $\mathrm{P}$ et al. The syndrome of diabetes insipidus, diabetes mellitus optic atrophy, deafness, and other abnormalities (DIDMOAD-syndrome). Two affected sibs and a short review of the literature (98 cases). Klin Wochenschr 1982; 60: 471-475.

139 Barrett TG, Bundley SE, Macleod AF. Neurodegeneration and diabetes: UK nationwide study of Wolfram (DIDMOAD) syndrome. Lancet 1995; 346: 1458-1463.

140 Scolding NJ, Kellar-Wood HF, Shaw C, Shneerson JM, Antoun N. Wolfram syndrome: hereditary diabetes mellitus with brainstem and optic atrophy. Ann Neurol 1996; 9: 352-360.

141 Barrett TG, Bundey SE, Fielder AR, Good PA. Optic atrophy in Wolfram (DIDMOAD) syndrome. Eye 1997; 11: 882-888

142 Barrett TG, Bundey SE. Wolfram (DIDMOAD) syndrome. J Med Genet 1997; 34: 838-841.

143 Al-Till M, Jarrah NS, Ajlouni KM. Ophthalmologic findings in fifteen patients with Wolfram syndrome. Eur J Ophthalmol 2002; 12: 84-88.

144 Simsek E, Simsek T, Tekgul S, Hosal S, Seyrantepe V, Aktan G. Wolfram (DIDMOAD) syndrome: a multidisciplinary clinical study in nine Turkish patients and review of the literature. Acta Paediatr 2002; 92: 55-61.

145 Castro FJ, Barrio J, Perena MF, Palomar MT, Cristobal JA. Uncommon ophthalmologic findings associated with Wolfram syndrome. Acta Ophthalmol Scand 2000; 78: 118-119.

146 Swift RG, Perkins DO, Chase CL, Sadler DB, Swift M. Psychiatric disorders in 36 families with Wolfram syndrome. Am J Psychiatry 1991; 148: 775-779.

147 Rando TA, Horton JC, Layzer RB. Wolfram syndrome: evidence of a diffuse neurodegenerative disease by magnetic resonance imaging. Neurology 1992; 42: 1220-1224.

148 Kinsley BT, Swift M, Dumont RH, Swift RG. Morbidity and mortality in the Wolfram syndrome. Diabetes Care 1995; 18: 1566-1570.

149 Borgna-Pignatti C, Marradi P, Pinelli L, Monetti N, Patrini C. Thiamine-responsive anemia in DIDMOAD syndrome. J Pediatr 1989; 114: 405-410.

150 Biousse V, Newman NJ. Neuro-ophthalmology of mitochondrial disorders. Curr Opin Neurol 2003; 16: 35-43.

151 Bundey S, Pulton K, Whitwell H, Curtis E, Brown IAR, Fielder AR. Mitochondrial abnormalities in the DIDMOAD syndrome. J Inherited Metab Dis 1992; 15: 315-319.

152 Barrientos A, Casademont J, Saiz A, Cardellach F, Volpini $\mathrm{V}$, Solans A et al. Autosomal recessive Wolfram syndrome associated with an 8.5-kb mtDNA single deletion. Am J Hum Genet 1996; 58: 963-970.

153 Polymeropoulos MH, Swift RG, Swift M. Linkage of the gene for Wolfram syndrome to markers on the short arm of chromosome 4. Nature Genet 1994; 8: 95.

154 Collier DA, Barrett TG, Curtis D, Macleod A, Arranz MJ, Maassen JA et al. Linkage of Wolfram syndrome to 
chromosome 4p16.1 and evidence for heterogeneity. Am J Hum Genet 1996; 59: 855-863.

155 Van Den Ouweland JM, Cryns K, Pennings RJ, Walraven I Janssen GM, Maassen JA et al. Molecular characterization of WFS1 in patients with Wolfram syndrome. J Mol Diagn 2003; 5: 88-95.

156 Cryns K, Pfister M, Pennings RJ, Bom SJ, Flothmann K, Caethoven $\mathrm{G}$ et al. Mutations in the WFS1 gene that cause low-frequency sensorineural hearing loss are small noninactivating mutations. Hum Genet 2002; 110: 389-394.

157 Barrientos A, Volpini V, Casademont J, Genís D, Nanzanares J-M, Ferrer I et al. A nuclear defect in the 4p16 region predisposes to multiple mitochondrial DNA deletions in families with Wolfram syndrome. J Clin Invest 1996; 97: 1570-1576.

158 Hofmann S, Bezold R, Jaksch M, Obermaier-Kusser B, Mertens S, Kaufhold P et al. Wolfram (DIDMOAD) syndrome and Leber hereditary optic neuropathy (LHON) are associated with distinct mitrochondrial DNA haplotypes. Genomics 1997; 39: 8-18.

159 Ajlouni K, Jarrah N, El-Khateeb M, El-Zaheri M, El Shanti $\mathrm{H}$, Lidral A. Wolfram syndrome: identification of a phenotypic and genotypic variant from Jordan. Am J Med Genet 2002; 115: 61-65.

160 Behr C. Die komplizierte, hereditar-familare optikusatrophie des kindesalters: ein bisher nicht beschriebener symptomkomplex. Klin Montasbl Augenheilkd 1909; 47: 138-160.

161 Francois J. Mode d'heredite des heredo-degenerescences du nerf optique. J Genet Hum 1966; 15: 147-220.

162 Francois J. Les atrophies optiques hereditaires. J Genet Hum 1976; 24: 183-200.

163 Costeff H, Gadoth N, Apter N, Prialnic M, Savir H. A familial syndrome of infantile optic atrophy, movement disorder, and spastic paraplegia. Neurology 1989; 39: 595-597.

164 Sheffer RN, Zlotogora J, Elpeleg ON, Raz J, Ben-Ezra D. Behr's syndrome and 3-methylglutaconic aciduria. Am J Ophthalmol 1992; 114: 494-497.

165 Costeff H, Elpeleg O, Apter N, Divry P, Gadoth N 3-Methylglutaconic aciduria in 'optic atrophy plus. Ann Neurol 1993; 33: 103-104.

166 Anikster Y, Kleta R, Shaag A, Gahl WA, Elpeleg O. Type III 3-methylglutaconic aciduria (optic atrophy plus syndrome, or Costeff optic atrophy syndrome): identification of the OPA3 gene and its founder mutation in Iraqi Jews. Am J Hum Genet 2001; 69: 1218-1224.

167 Lynch DR, Farmer J. Practical approaches to neurogenetic disease. J Neuro-ophthalmol 2002; 22: 297-304.

168 Geoffroy G, Barbeau A, Breton G, Lemieux B, Aube M, Leger $\mathrm{C}$ et al. Clinical description roentgenologicevaluation of patients with Friedreich's ataxia. Can J Neurol Sci 1976; 3: 279-286.

169 Carroll WM, Kriss A, Baraitser M, Barrett G, Halliday AM The incidence and nature of visual pathway involvement in Friedreich's ataxia: a clinical and visual evoked potential study of 22 patients. Brain 1980; 103: 413-434.

170 Livingstone IR, Mastaglia FL, Edis R, Howe JW. Visual involvement in Friedreich's ataxia and hereditary spastic ataxia: a clinical and visual evoked response study. Arch Neurol 1981; 38: 75-79.

171 Wenzel W, Camacho L, Claus D, Aschoff J. Visually evoked potentials in Friedreich's ataxia. Adv Neurol 1982; 32: 131-139.
172 Müller-Felber W, Rossmanith T, Spes C, Chamberlain S, Pongratz D, Deufel T. The clinical spectrum of Friedreich's ataxia in German families showing linkage to the FRDA locus on chromosome 9. Clin Invest 1993; 71: 109-114.

173 Montermini L, Richter A, Morgan K, Justice CM, Julien D, Castellotti B et al. Phenotypic variability in Friedreich ataxia: role of the associated GAA triplet repeat expansion. Ann Neurol 1997; 41: 675-682.

174 Givre SJ, Wall M, Kardon RH. Visual loss and recovery in a patient with Friedreich ataxia. J Neuro-ophthalmology 2000; 20: 229-233.

175 Belal S, Hentati F, Ben Hamida C, Ben Hamida M. Friedreich's ataxia-vitamin $\mathrm{E}$ responsive type. The chromosome 8 locus. Clin Neurosci 1995; 3: 39-42.

176 Klockgether T, Wullner U, Spauschus A, Evert B. The molecular biology of the autosomal-dominant cerebellar ataxias. Mov Disord 2000; 15: 604-612.

177 Abe T, Abe K, Aoki M, Itoyama Y, Tamai M. Ocular changes in patients with spinocerebellar degeneration and repeated trinucleotide expansion of spinocerebellar ataxia type 1 gene. Arch Ophthalmol 1997; 115: 231-236.

178 Harding AE. The clinical features and classification of late onset autosomal dominant cerebellar ataxias: A study of 11 families, including descendants of the 'Drew family of Walworth. Brain 1982; 105: 1-28.

179 Durr A, Brice A, Lepage-Lezin A, Cancel G, Smadja D, Vernant JC et al. Autosomal dominant cerebellar ataxia type I linked to chromosome 12q (SCA2: spinocerebellar ataxia type 2). Clin Neurosci 1995; 3: 12-16.

180 Kuhlenbaumer G, Young P, Hunermund G, Ringelstein B, Stogbauer F. Clinical features and molecular genetics of hereditary peripheral neuropathies. J Neurol 2002; 249: 1629-1650.

181 Chalmers RM, Bird AC, Harding AE. Autosomal dominant optic atrophy with asymptomatic peripheral neuropathy. J Neurol Neurosurg Psychiatry 1996; 60: 195-196.

182 Chalmers RM, Riordan-Eva P, Wood NW. Autosomal recessive inheritance of hereditary motor and sensory neuropathy with optic atrophy. J Neurol Neurosurg Psychiatry 1997; 62: 385-387.

183 Gadoth N, Gordon CR, Bleich N, Pratt H. Three modality evoked potentials in Charcot-Marie-Tooth Disease (HMSN-1). Brain Dev 1991; 13: 91-94.

184 Rizzo JF (III, Lessell S, Liebman SD. Optic atrophy in familial dysautonomia. Am J Ophthalmol 1986; 102: 463-467.

185 Groom M, Kay MD, Corrent GF. Optic neuropathy in familial dysautonomia. J Neuro-ophthalmology 1997; 17: 101-102.

186 Makhoul J, Cordonnier M, Van Nechel C. Optic neuropathy in Strumpell-Lorrain disease: presentation of a clinical case and literature review. Bull Soc Belge Ophthalmol 2002; 286: 9-14.

187 Carelli V, Ross-Cisneros FN, Sadun AA. Optic nerve degeneration and mitochondrial dysfunction: genetic and acquired optic neuropathies. Neurochem Int 2002; 40: 573-584.

188 Shoubridge EA. Cytochrome c oxidase deficiency. Am J Med Genet 2001; 106: 46-52.

189 Biousse V, Newman NJ. Neuro-ophthalmology of mitochondrial diseases. Semin Neurol. 2001; 21: 275-291.

190 Carelli V, Sadun AA. Optic neuropathy in LHON and Leigh Syndrome. Ophthalmology 2001; 108: 1172-1173. 